Indexed by

\title{
THE INFLUENCE OF SOCIOECONOMIC STATUS ON THE MODES CHOICE OF TRANSPORTATION IN MANADO CITY
}

Crossref

KOBSON

Foogle

$\mathrm{R} \partial \mathrm{AD}=$

\section{Tampanatu P.F. Sompie}

Civil Engineering Department, Manado State Polytechnic, Indonesia

Key words: socioeconomic status, mode choice, sem-amos, multinomial logit doi:10.5937/jaes0-32811

Cite article:

P.F. Sompie T. (2022) THE INFLUENCE OF SOCIOECONOMIC STATUS ON THE MODES CHOICE OF TRANSPORTATION IN MANADO CITY, Journal of Applied Engineering Science, 20(1), 101 - 108, DOI:10.5937/ jaes0-32811

Online aceess of full paper is available at: www.engineeringscience.rs/browse-issues 


\title{
THE INFLUENCE OF SOCIOECONOMIC STATUS ON THE MODES CHOICE OF TRANSPORTATION IN MANADO CITY
}

\author{
Tampanatu P.F. Sompie.* \\ Civil Engineering Department, Manado State Polytechnic, Indonesia
}

Good infrastructure and transportation facilities move people and goods take place safely and economically in terms of time and cost. The trips made by people on weekdays or weekends affect environmental conditions in the area. The purpose of this paper is to find out the influence of socioeconomic status on modes choice of transportation both on weekdays and weekends. The study location is in Manado Municipality. There are 3 (three) modes of transportation reviewed, i.e., private cars, motorcycles, and public transportation; indicators of socioeconomic status of transportation users are age, education, occupation, income, number of family members, and vehicle ownership; data retrieval regarding the modes of transportation and socioeconomic status of travelers through questionnaire surveys. SEM-AMOS was used to measure the validity and reliability of the data, and the probability of the mode choice on weekdays and weekends was analyzed using multinomial logistic regression analysis. The results showed that the socioeconomic status of travelers has an influence on the mode choice of transportation by $49.2 \%$ on weekends and $49.5 \%$ on weekdays. Furthermore, the probability of transportation mode choice on weekends is the car by $88.4 \%$, and on weekdays is motorcycles by $71.6 \%$

Key words: socioeconomic status, mode choice, sem-amos, multinomial logit

\section{INTRODUCTION}

People travel to do daily activities such as work, shopping, and recreation. Policymakers seek to manage travel behavior through urban transportation planning, create a good and organized environment, reduce the use of private vehicles, replace them with non-motorized vehicles, and shorten mileage in neighborhoods with high densities and diverse activities [1]. Policymakers made policies to convince people to switch from individual motorized vehicles to public or non-motorized transportation [2]. On the other hand, the government must continuously improve the quality of public transportation since the demand for travel served by public vehicles and private vehicles will depend on the appearance of each mode in competition with other modes [3]. The available modes of transportation are alternatives to choose from, such as public transportation modes, cars, and motorcycles, where each mode has different attributes in terms of travel time, cost, and comfort [4]. The movement to work in developed countries is usually more accessible by using public transportation because of the punctuality, good level of service and the cost is relatively cheaper than private transportation. On the other hand, people still use private cars to work in developing countries, even though more expensive, because public transportation cannot meet punctuality and convenience [3]. [5] analyzed indicators such as travel time, the built environment, and socioeconomic conditions, which significantly influence the mode used in schools. [6] explained that activity pattern-based models consider socioeconomic variables. Furthermore, [7] stated that Socio-demographic variables (age, household composition, income, gender, and car ownership) were significant factors influencing travel behavior. Whereas age, gender, and occupation affect the mode choice behavior for shopping mall trips [8]. Age, gender, marital status, income, private vehicle ownership, travel time, and costs influenced commuter workers' use of road public transportation [9]. Model explaining trip generation (why the trip was people made) [10]; travel behavior [11]; and market segmentation studies in travel behavior research [2] still rely heavily on the individual socioeconomic characteristics of travelers. In addition, children's travel behavior should also receive attention because it will contribute to adult activity patterns; the socioeconomic and demographic factors also affect the children's involvement in traveling to take part in extra-curricular activities [12]. While socioeconomic, travel mode attributes and attitude factors also affect the elderly mode choice [13]. Besides the trips made on weekdays, weekends also affect activity patterns in transportation system planning [14]. [15] stated that travel demand modeling has traditionally focused on the modeling-based activity patterns of individual trips for five working days in a week (Monday-Friday). However, in recent years, amount of trips and intensity of traffic congestion on weekends has increased to near the level of congestion on weekdays. Furthermore, the peak period of weekend trips is unlike trips on weekdays [15]. The peak period for weekend trips occurs during the middle of the day [16]. [17] added that most of the activities of the weekend tend to begin in the middle of the day. [14] found that the workers and the students show the behavior of the journey is stable on weekdays, but the weekday activities of non-workers and weekend activities of all respondents were generally more random in normal conditions. [18] studied transportation mode choice behavior among commuters using private vehicles compared to public transportation. Using the Logit Model and Structural Equation 
Modeling analysis method, it concluded that the application of bus lanes does not have a significant impact on the shift from private vehicle users to public transport. [19] measured the level of people's satisfaction with public transport services. Results of their research concluded that satisfaction depends on the user's quality of service and socio-economic background. [20] identified the effect of changes in population distribution and urban functional changes against the distance of a trip to school using public transport and private car by using multinomial logistic regression analysis. The research concludes that the habit of using vehicles and age factors make private vehicles the primary mode of transportation. The population density variable in Jakarta and its surrounding cities does not affect the choice of the transportation mode both on the railway and public transport highway [9]. Gender affects transportation mode choice, and females prefer to use the commuter line than males [21].

\section{MODEL AND METHODOLOGY}

Manado is the capital city of North Sulawesi Province, and geographically it is located between $1^{\circ} 30^{\prime}-1^{\circ} 40^{\prime}$ North Latitude and $124^{\circ} 40^{\prime}-126^{\circ} 50^{\prime}$ East Longitude; has an area of $162,53 \mathrm{~km} 2$, and a population of 433.640 people. The number of motorized vehicles in 2019 was 497.984 vehicles [22]. Data of this study was obtained through questionnaire surveys. The validity and reliability of the data were measured using SEM-AMOS. To analyze the probability of the mode choice on weekdays and weekends was using Multinomial logistic regression analysis. The data collected is socioeconomic data of the individual, including home address and the primary activity location to determine the origin and destination zone of the trip, data on gender, age, education, household position, and type of main activity; and socioeconomic data of the household, including the number of a household member, vehicle ownership, and total income. The modes of transport used are cars, motorcycles, and public transportation; then the modal information data explaining the reasons why using the mode concerned and the costs incurred as a result of using the mode is. This information will provide the variable costs required for each mode; also information about the level of accessibility, security, and comfort of the mode of transportation used. Structural Equation Modeling (SEM) is a set of statistical techniques that allows the simultaneous testing of a series of relatively complex relationships. Between one or more dependent variables can build the relationship with one or more independent variables. Structural Equation Modelling (SEM) is an integrated approach between Factor Analysis, Structural Modeling, and Path Analysis.; also called Path Analysis or Confirmatory Factor Analysis [23]. Various studies can use two models, i.e., the descriptive model, the measurement model, and the predictive model, which is the structural model (causal model). Measurement model can be done partially or as a whole; performed on each construct (single
Table 1: Respondents' profiles

\begin{tabular}{|c|c|c|}
\hline & Amount & $\%$ \\
\hline \multicolumn{3}{|l|}{ Age } \\
\hline$\leq 19$ years old & 46 & 22.01 \\
\hline $\begin{array}{c}20-29 \text { years } \\
\text { old }\end{array}$ & 49 & 23.45 \\
\hline $30-39$ years old & 36 & 17.22 \\
\hline $\begin{array}{c}40-49 \text { years } \\
\text { old }\end{array}$ & 60 & 28.71 \\
\hline$\geq 50$ years old & 18 & 8.61 \\
\hline
\end{tabular}

Gender

\begin{tabular}{|c|c|c|}
\hline Male & 123 & 58.85 \\
\hline Female & 86 & 41.15 \\
\hline
\end{tabular}

\begin{tabular}{|c|c|c|}
\hline \multicolumn{2}{|c|}{ Education } & \\
\hline $\begin{array}{c}\text { Junior High } \\
\text { School }\end{array}$ & 39 & 18.66 \\
\hline $\begin{array}{c}\text { Senior High } \\
\text { School }\end{array}$ & 65 & 31.10 \\
\hline Under Graduate & 85 & 40.67 \\
\hline Post Graduate & 20 & 9.57 \\
\hline
\end{tabular}

Family Size

\begin{tabular}{|c|c|c|}
\hline 1 Person & 4 & 1.91 \\
\hline 2 Persons & 6 & 2.87 \\
\hline 3 Persons & 38 & 18.18 \\
\hline 4 Persons & 68 & 32.54 \\
\hline 5 Persons & 93 & 44.50 \\
\hline $\begin{array}{c}\text { Occupation } \\
\text { Students }\end{array}$ & 64 & 30.62 \\
\hline $\begin{array}{c}\text { Government } \\
\text { employees }\end{array}$ & 77 & 36.84 \\
\hline $\begin{array}{c}\text { Soldier/ } \\
\text { Policeman }\end{array}$ & 6 & 2.87 \\
\hline $\begin{array}{c}\text { Employees of } \\
\text { state-owned } \\
\text { enterprises }\end{array}$ & 60 & 28.71 \\
\hline $\begin{array}{c}\text { Private } \\
\text { employees }\end{array}$ & 6 & \\
\hline
\end{tabular}

Istraživanja i projektovanja za privredu ISSN 1451-4117 Journal of Applied Engineering Science Vol. 20, No. 1, 2022 
measurement model) and (multidimensional model). The structural model will result in an assessment of predictive validity. The approach used for the measurement model analysis is Confirmatory Factor Analysis. Validity test; intended to determine whether the questions in the questionnaire are quite representative so to measure whether a questionnaire is valid or not is using validity test. A questionnaire is said to be valid if the questions in the questionnaire can reveal something that the questionnaire will measure. If the loading factor is $>0.50$, it can be said to be valid. Reliability test; is the index that indicates the extent to which the measuring instruments are reliable or trustworthy. Reliability is a measure of internal consistency of the indicators of a formation variable that show the degree to which each indicator indicates a commonly formed variable. To measure the level of consistency of the research instrument is intending a reliability test. In this study, in calculating reliability using composite (construct), reliability with a cut-off value is a minimum of 0.7 . The calculation is as follows:

$$
C R=\frac{\left(\sum \text { standardized loading }\right)^{2}}{\left(\sum \text { standardized loading }\right)^{2}+\sum e_{j}}
$$

The multinomial logit model used in this study determines the probability of choosing a private car, motorcycle, and public transportation by travelers traveling from home to places of activity and returning home. The utility value of the transportation mode is influencing the probability of a mode of transportation. The mode of transportation that wants to know will compare the probability of being chosen with the utility value of other transportation modes. The utility value used for the equation of multinomial logit is the average value on each mode of transportation variable. People's choice of mode utility is approaching the mode choice model. Utility represents an advantage or attractiveness of a commodity, which includes the mode of transportation, where each commodity has a utility that is a combination of the inherent attributes [4]. The multinomial logit model is a simple model of the random utility model. There are two components in the utility function equation, namely the deterministic component and error component The utility functions equation is:

$$
U_{t, i}=V\left(S_{t}\right)+V\left(X_{i}\right) V\left(S_{t}, X_{i}\right)+\varepsilon_{t i}
$$

where :

Ut,i : utility for alternative i for individual $t$

$\mathbf{V}(\mathbf{S t})$ : deterministic utility component related to individual characteristics $t$

$\mathbf{V}(\mathbf{X i})$ : deterministic utility component related to the alternative attribute of choice $i$

$\mathbf{V}(\mathbf{S t}, \mathbf{X i})$ : deterministic utility component interactions between related to individual characteristics $t$ and the alternative attributes of choice $i$

$\mathcal{E}$ ti : random utility component or error component
The logit model is built based on the following assumptions: error components distributed in the Gumbel distribution; error components are distributed independently and identically among alternatives (IID: independently and identically distributed); and the error component is distributed independently and identically among individuals studied (IIA: independence of irrelevant alternatives). This model provides the probability of choice of each alternative as a systematic function of all alternatives. The general formula for option i from the set of alternative $\mathrm{j}$ is :

$\operatorname{Pr}\left(\mathbb{i}_{i}\right)=\frac{\exp \left(V_{i}\right)}{\sum_{j=1}^{j} \exp \left(V_{j}\right)}$

where :

$\operatorname{Pr}(\mathbf{i})$ : the probability of decision-makers choosing alternative $i$

Vi : the systematic utility component of alternative $i$

$\mathbf{V j}$ : the systematic utility component of alternative $j$ An illustration of the multinomial logit model in a decision-making case that has three available alternatives in the form of car (C), motorcycle (M), and public transportation (PT), then an example of the probability to choose an alternative car is :

$$
\operatorname{Pr}_{(C)}=\frac{\exp \left(V_{C}\right)}{\exp \left(V_{C}\right)+\exp \left(V_{M}\right)+\exp \left(V_{P T}\right)}
$$

$\mathrm{V}_{\mathrm{C}}, \mathrm{V}_{\mathrm{M}}$, and $\mathrm{V}_{\mathrm{PT}}$ are systematic car, motorcycle, and public transportation utilities. A thing that needs attention is that the probability value will increase with the increase in the utility systematic component if the other utilities are kept constant.

\section{RESULTS AND DISCUSSION}

\section{Analysis of the model using Structural Equation Modeling with the AMOS program}

\section{Description of Socio-Economic Latent Variable (X1)}

The latent variable of socioeconomic status (X1) has indicators that include age (X1.1), education (X1.2), occupation (X1.3), income (X1.4), number of family members (X1.5), and vehicle ownership (X1.6).

Table 2: Description of indicators of variables X1

\begin{tabular}{|c|c|c|c|}
\hline No & X1 & Mean & $\begin{array}{c}\text { Standard } \\
\text { Deviation }\end{array}$ \\
\hline 1 & $\mathrm{X} 1.1$ & 4.2967 & .65636 \\
\hline 2 & $\mathrm{X} 1.2$ & 4.3732 & .89036 \\
\hline 3 & $\mathrm{X} 1.3$ & 4.4163 & .70296 \\
\hline 4 & $\mathrm{X} 1.4$ & 4.4258 & .68325 \\
\hline 5 & $\mathrm{X} 1.5$ & 4.1531 & .89093 \\
\hline 6 & $\mathrm{X} 1.6$ & 4.2297 & .79957 \\
\hline
\end{tabular}


The average value of 4,3158 and standard deviation of 0,7706 means that overall respondents tend to agree with the indicator statements of the socioeconomic status variable (X1).

\section{Description of Mode of Transport Latent Variable (Y)}

The latent variable mode of transport $(\mathrm{Y})$ as indicators of private cars (Y1), motorcycles (Y2), and public transport (Y3).

Table 3: Description of indicators of the variable $Y$

\begin{tabular}{|c|c|c|c|}
\hline No & Y & Mean & $\begin{array}{c}\text { Standard } \\
\text { Deviation }\end{array}$ \\
\hline 1 & Y1 & 4.4019 & .96137 \\
\hline 2 & Y2 & 4.2440 & .90553 \\
\hline 3 & Y3 & 4.1196 & .88798 \\
\hline
\end{tabular}

An average value of 4,255 and a standard deviation of 0.918 means that overall respondents are likely to agree on the mode of transportation variable $(Y)$. Each latent variable, i.e., socioeconomic status $(X 1)$ and mode of transportation $(\mathrm{Y})$, carried a validity test using Confirmatory Factor Analysis.

\section{Latent Variable of Socioeconomic Status (X1)}

Socioeconomic Status (X1) is an exogenous latent variable (variable latent exogen) measured from 6 (six) variables: age (X1.1), education (X1.2), occupation (X1.3), income (X1.4), number of family members (X1.5) and vehicle ownership (X1.6). To determine whether the socioeconomic status (X1) is a valid latent variable is using Confirmatory Factor Analysis. The results with the AMOS program can be seen in figure 1 below:

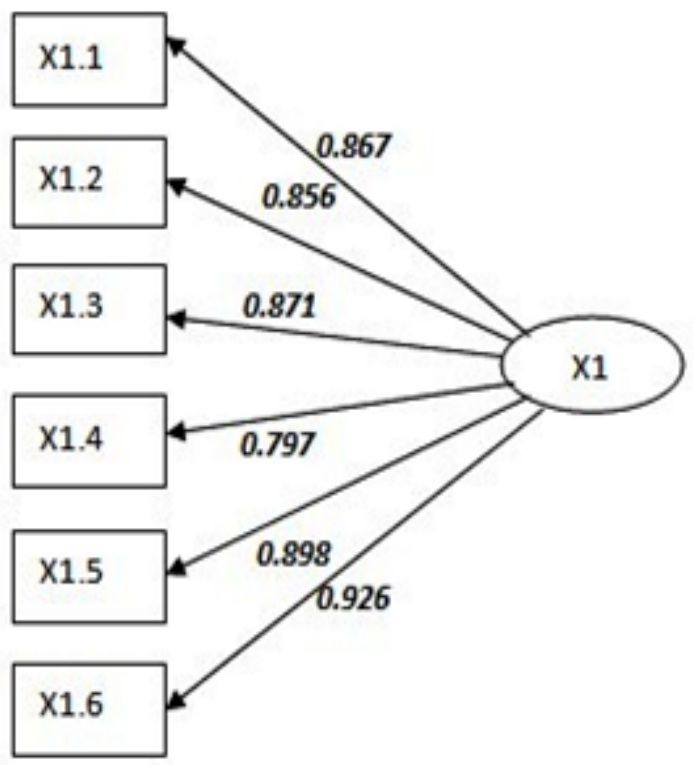

Figure 1: The validity test of socioeconomic status (X1)
The six loading values are more significant than 0.5 , and to measure socioeconomic status (X1), namely: age (X1.1), education (X1.2), occupation (X1.3), income ( X1.4), number of family members (X1.5), and vehicle ownership (X1.6) can use all indicators.

\section{Latent Variable Model of Transportation (Y)}

Modes of transportation $(Y)$ is an exogenous latent variable measured from 3 (three) variables, i.e., private cars (Y1), motorcycles (Y2), and public transportation (Y3). To determine whether the modes of transportation $(Y)$ is a valid latent variable is using Confirmatory Factor Analysis, and the results can be seen in figure 2 below:

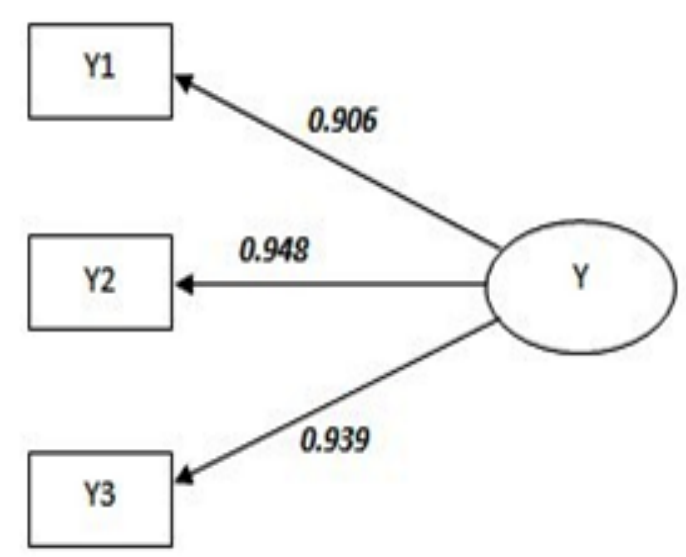

Figure 2: The validity test of modes of transportation $(Y)$

To measure the modes of transportation (Y), i.e., private cars (Y1), motorcycles (Y2), and public transportation (Y3) can use all the indicators because the three loading values are more significant than 0.5 . From table 4 above, it turns out that the latent variable of socioeconomic status (X1) gives the value of CR of 0.949 above the cut-off value of 0.7 ; therefore, the socioeconomic status (X1) is reliable. Likewise, for each indicator, all p-value error variances are less than 0.05 , which is said to be reliable. From table 5 above, it turns out that the latent variable mode of transportation ( $Y$ ) gives the value of CR of 0.951 above the cut-off of 0.7 , so the mode of transportation $(\mathrm{Y})$ is reliable. Similarly, Likewise for each indicator, all $\mathrm{p}$-value error variances are less than 0.05 , which is said to be reliable.

\section{Multinomial Regression Model For Modes of Transportation}

There are three modes of choice of transportation, i.e., cars, motorcycles, and public transportation; to analyze the probability for choosing the mode at the weekend and weekday using multinomial logistic regression. 
Table 4: Reliability test $X 1$

\begin{tabular}{|c|c|c|c|c|c|c|}
\hline $\mathrm{X} 1$ & $\begin{array}{l}p \text {-value error } \\
\text { variance }\end{array}$ & Description & Loading $(\Lambda)$ & $\Lambda^{2}$ & $1-\Lambda^{2}$ & CR \\
\hline $\mathrm{X} 1.1$ & 0.000 & Reliable & 0.867 & 0.751689 & 0.248311 & \multirow{7}{*}{0.949} \\
\hline $\mathrm{X} 1.2$ & 0.000 & Reliable & 0.856 & 0.732736 & 0.267264 & \\
\hline $\mathrm{X} 1.3$ & 0.000 & Reliable & 0.871 & 0.758641 & 0.241359 & \\
\hline $\mathrm{X} 1.4$ & 0.000 & Reliable & 0.797 & 0.635209 & 0.364791 & \\
\hline$\times 1.5$ & 0.000 & Reliable & 0.898 & 0.806404 & 0.193596 & \\
\hline X1.6 & 0.000 & Reliable & 0.926 & 0.857476 & 0.142524 & \\
\hline Total & & & 5.215 & & 1.45784 & \\
\hline
\end{tabular}

Table 5: Reliability test $Y$

\begin{tabular}{|c|c|c|c|c|c|c|}
\hline Y1 & $\begin{array}{l}p \text {-value error } \\
\text { variance }\end{array}$ & Description & Loading $(\Lambda)$ & $\Lambda^{2}$ & $1-\Lambda^{2}$ & CR \\
\hline Y1 & 0.000 & Reliable & 0.906 & 0.820836 & 0.179164 & \multirow{4}{*}{0.951} \\
\hline Y2 & 0.000 & Reliable & 0.948 & 0.898704 & 0.101296 & \\
\hline Y3 & 0.000 & Reliable & 0.939 & 0.881721 & 0.118279 & \\
\hline Total & & & 2.793 & & 0.398739 & \\
\hline
\end{tabular}

Table 6: Model Fitting Information of mode choice of transportation on the weekend based on socioeconomic status

\begin{tabular}{|c|c|c|c|c|}
\hline \multirow{2}{*}{$\begin{array}{c}\text { Model of mode choice of transportation } \\
\text { based on socioeconomic status }\end{array}$} & Model Fitting Criteria & \multicolumn{3}{|c|}{ Likelihood Ratio Tests } \\
\cline { 2 - 5 } & -2 Log Likelihood & Chi-Square & df & Sig. \\
\hline Null & 210.574 & & & \\
\hline Final & 90.306 & 120.268 & 40 & .000 \\
\hline
\end{tabular}

\section{Multinomial Regression for Mode of Transportation on Weekend}

Mode Choice of Transportation based on Socioeconomic Status Model Fitting Information \& Goodness-of-fit to determine whether the model is significant or not. Modeling of a mode choice of transportation that consists of cars, motorcycles, and public transportation based on the socioeconomic status (X1), which has indicators of age (X1.1), education (X1.2), occupation (X1.3), income (X1.4), the number family members (X1.5) and vehicle ownership (X1.6) beginning with testing the model. For model fitting information, the model is significant if Sig. $\leq \alpha$ or at the Goodness-of-fit; the model is significant if Sig. $\geq \alpha$. Based on table 6 above, the likelihood ratio test value gives Sig. $=0.000$, less than $\alpha=0.05$. It shows that the model of mode choice of transportation is fit, which means that the socioeconomic status (X1), which consists of indicators of age (X1.1), education (X1.2), occupation (X1.3), income (X1.4), the number of family members (X1.5) and vehicle ownership (X1.6) affect the modes choice of transportation (cars, motorcycles, and public transportation).
Table 7: Pseudo R-Square

\begin{tabular}{|c|c|}
\hline Cox and Snell & .438 \\
\hline Nagelkerke & .492 \\
\hline McFadden & .262 \\
\hline
\end{tabular}

Based on the Pseudo R-Square to see the probability of the influence of independent variables on a response variable. Pseudo R-Square in Nagalkerke gives a value of 0.492 ; this shows that the Socioeconomic Status (X1), which consists of 6 (six) indicators of age (X1.1), education (X1.2), occupation (X1.3), income (X1.4), the number of family members (X1.5) and vehicle ownership (X1.6) influence modes choice of transportation (cars, motorcycles, and public transportation) of 0.492 or $49.2 \%$ Furthermore, to find out how accurate in modes choice of transportation based on the socioeconomic status variable $(\mathrm{X} 1)$, which has indicators of age (X1.1), education (X1.2), occupation (X1.3), income (X1.4), number of family members (X1.5) and vehicle ownership (X1.6) is presented in the following table. 
Table 8: Classification of modes choice of transportation on the weekend based on socioeconomic status

\begin{tabular}{|c|c|c|c|c|}
\hline \multirow{2}{*}{ Observed } & \multicolumn{4}{|c|}{ Predicted } \\
\cline { 2 - 5 } & 1 (Cars) & 2 (Motorcycles) & 3 (Public Transportation) & Percent Correct \\
\hline 1 (Cars) & 84 & 11 & 0 & $88.4 \%$ \\
\hline 2 (Motorcycles) & 62 & 15 & 1 & $19.2 \%$ \\
\hline 3 (Public Transportation) & 14 & 5 & 17 & $47.2 \%$ \\
\hline Overall Percentage & $76.6 \%$ & $14.8 \%$ & $8.6 \%$ & $55.5 \%$ \\
\hline
\end{tabular}

Table 8 shows that the classification accuracy of 55.5 percent, while the specification of modes choice of transportation for cars is 88.4 percent, motorcycles is 19.2 percent, and public transportation is 47.2 percent.

\section{Multinomial Regression for Mode of Transportation on Weekdays}

Mode Choice of Transportation Based on Socioeconomic Status. Modeling of modes choice of transportation that consists of cars, motorcycles, and public transportation based on the socioeconomic status (X1), which has indicators of age (X1.1), education (X1.2), occupation (X1.3), income (X1.4), the number of family members $(X 1.5)$ and vehicle ownership $(X 1.6)$ begins with a model test. Model Fitting Information \& Goodness-of-fit to determine whether the model is significant or not. For model fitting information, it is significant if the Sig. $\leq \alpha$; or for the Goodness-of-fit, model is significant if the Sig. $\geq \alpha$ Based on table 9 above, the Likelihood ratio Test value gives the Sig. 0.000, which is less than $\alpha=0.05$.
This shows that the model of mode choice of transportation is fit, which means that the socioeconomic status (X1) which consists of indicators of age (X1.1), education (X1.2), occupation (X1.3), income (X1.4)), the number of family members (X1.5) and vehicle ownership (X1.6) affect the modes choice of transportation (cars, motorcycles, and public transportation). Based on the Pseudo R-Square to see the probability of the influence of independent variables on a response variable. Pseudo $\mathrm{R}$-Square in Nagalkerke gives a value of 0.495 ; this indicates that the Socioeconomic Status (X1), which consists of 6 (six) indicators of age (X1.1), education (X1.2), occupation (X1.3), income (X1.4), the number of family members (X1.5) and vehicle ownership (X1.6) influence modes choice of transportation (cars, motorcycles, and public transportation) of 0.495 or $49.5 \%$ The accurate modes choice of transportation based on the socioeconomic status variable $(\mathrm{X} 1)$ is presented in the following table.

Table 9: Model Fitting Information of mode choice of transportation based on the socioeconomic status on a weekday

\begin{tabular}{|c|c|c|c|c|}
\hline \multirow{2}{*}{$\begin{array}{c}\text { Model of mode choice of transportation based } \\
\text { on the socioeconomic status on a weekday }\end{array}$} & Model Fitting Criteria & \multicolumn{3}{|c|}{ Likelihood Ratio Tests } \\
\cline { 2 - 5 } & -2 Log Likelihood & $\begin{array}{c}\text { Chi- } \\
\text { Square }\end{array}$ & df & Sig. \\
\hline Null & 369.665 & & & \\
\hline Final & 248.619 & 121.047 & 44 & .000 \\
\hline
\end{tabular}

Table 10: Pseudo R-Square

\begin{tabular}{|c|c|}
\hline Cox and Snell & .440 \\
\hline Nagelkerke & .495 \\
\hline McFadden & .264 \\
\hline
\end{tabular}

Based on the Pseudo R-Square to see the probability of the influence of independent variables on a response variable. Pseudo R-Square in Nagalkerke gives a value of 0.495 ; this indicates that the Socioeconomic Status (X1), which consists of 6 (six) indicators of age (X1.1), education (X1.2), occupation (X1.3), income (X1.4), the number of family members (X1.5) and vehicle ownership (X1.6) influence modes choice of transportation (cars, motorcycles, and public transportation) of 0.495 or $49.5 \%$ The accurate modes choice of transportation based on the socioeconomic status variable (X1) is presented in the following table. 
Table 11: Classification of modes choice of transportation on weekday based on socioeconomic status

\begin{tabular}{|c|c|c|c|c|}
\hline \multirow{2}{*}{ Observed } & \multicolumn{4}{|c|}{ Predicted } \\
\cline { 2 - 5 } & 1 (Cars) & 2 (Motorcycles) & 3 (Public Transportation) & Percent Correct \\
\hline 1 (Cars) & 43 & 7 & 19 & $62.3 \%$ \\
\hline 2 (Motorcycles) & 10 & 53 & 11 & $71.6 \%$ \\
\hline 3 (Public Transportation) & 10 & 11 & 45 & $68.2 \%$ \\
\hline Overall Percentage & $30.1 \%$ & $34.0 \%$ & $35.9 \%$ & $67.5 \%$ \\
\hline
\end{tabular}

Table 11 shows the classification accuracy of 67.5 percent, while the specification of modes choice of transportation for cars is 62.3 percent, motorcycles is 71.6 percent, and public transportation is 68.2 percent. The study results can be used as a reference for the city government to formulate appropriate policies in urban transportation planning. The use of public transportation can be a solution in developing areas in overcoming congestion problems and assisting the movement of residents in their activities. However, public transportation is an inferior service compared to other modes [21]; therefore, the city government is strongly encouraged to improve public transportation facilities, establish routes that reach more expansive areas, and are accessible to residents.

\section{CONCLUSION}

Based on the results of the analysis using SEM-AMOS and Multinomial Regression Model, it can be concluded that: on the weekend; Socioeconomic status (X1) which consists of indicators of age (X1.1), education (X1.2), occupation (X1.3), income (X1.4), number of family members (X1.5) and ownership vehicle (X1.6) influences the modes choice of transportation $(\mathrm{Y})$ by 49.2 percent. Meanwhile, on the weekdays, socioeconomic status influences the modes choice of transportation by $49.5 \%$. The probability of the travelers in the modes choice of transportation for cars by 62.3 percent, motorcycles 71.6 percent, and public transportation 68.2 percent. Moreover, the probability of the travelers in the modes choice of transportation for cars was 88.4 percent, motorcycles 19.2 percent, and public transportation 47.2 percent. This study can help the city government understand the community's socio-economic aspects that affect transportation mode choice. Decision-makers in city government are encouraged to improve public transportation facilities.

\section{ACKNOWLEDGMENTS}

The author would like to thank Dr. Bambang Otok Widjanarko for the comments and assistance.

\section{REFERENCES}

1. Van Acker, V., Van Wee, B., \& Witlox, F. (2010). When transport geography meets social psychology: toward a conceptual model of travel behaviour. Transport Reviews, 30(2), 219-240.

2. Diana, M., \& Mokhtarian, P. (2009). Grouping travelers on the basis of their different car and transit levels of use. Transportation, 36, 4, 455-467.

3. Warpani, S. (1990). Merencanakan sistem perangkutan. Penerbit ITB, Bandung.

4. Kanafani, A. (1983). Transportation demand analysis. McGraw-Hill Inc, New York.

5. Roorda, M., Passmore, D., \& Miller, E. (2009). Including minor modes of transport in a tour-based mode choice model with household interactions. Journal of Transportation Engineering, 135, 12, 935-945.

6. de Abreu e Silva., Goulias, K. G., \& Dalal, P. (2011). A structural equation model of land use pattern, location choice, and travel behavior in southern California. 91st Transportation Research Board 28 Annual Meeting, Washington D.C. and publication in the Transportation Research 29 Record.

7. Curtis, C., \& Perkins, T. (2006). Travel behaviour : a review of recent literature. Working Paper No. 3: Travel Behaviour, Urbanet, Department of Urban and Regional Planning, Curtin University.

8. Meena, S., Patil, G. R., \& Mondal, A. (2019). Understanding mode choice decisions for shopping mall trips in metro cities of developing countries. Transportation Research Part F: Traffic Psychology and Behaviour, 64, 133-146.

9. Adwiluvito, H. (2019). Determinants of the mode choice of transportation for jabodetabek commuter workers with the multinomial multilevel logistics regression model. Indonesian Journal of Statistics and Its Applications, Vol 3, No 1, $49-61$.

10. Carrasco, J., \& Miller, E. (2006). Exploring the propensity to perform social activities: a social network approach. Transportation, 33, 5, 463-480. 
11. Eboli, L., Forciniti, C., \& Mazzulla, G. (2012). Exploring land use and transport interaction through structural equation modeling. Compendium of Papers, International Scientific Conference, 15th Edition of The Euro Working Group on Transportation, 10-13 September 2012, Paris.

12. Sener, I., Copperman, R., Pendyala, R., \& Bhat, C. (2008). An analysis of children's leisure activity engagement: examining the day of week, location, physical activity level, and fixity dimensions. Transportation, 35, 5, 673-696.

13. Omrani, H., Mamdoohi, A. R., \& Farzin, I. (2021). Taste variation of the elderly mode choice: the role of socioeconomic, attitude and behavior factors. International Journal of Transportation Engineering, Vol. 8, No.4, (30), 341-362.

14. Buliung, R., Roorda, M., \& Remmel, T. (2008). Exploring spatial variety in patterns of activity-travel behaviour: initial results from the Toronto travel-activity panel survey (TTAPS). Transportation, 35, 6, 697-722.

15. Sall, E., \& Bhat, C. (2007). An analysis of weekend work activity patterns in the San Francisco bay area. Transportation, 34, 2, 161-175.

16. Lockwood, A., Srinivasan, S., \& Bhat, C.R. (2005). An exploratory analysis of weekend activity patterns in the San Francisco bay area. Transport, Res. Rec. 1926, 70-78.
17. Ming, Z., \& Hunt, J. (2010). Exploring best-fit hazard functions and lifetime regression models for urban weekend activities: a case study. Journal of Transportation Engineering, 136, 3, 255-266.

18. Sutomo, H., Sugiyanto., Istiyanto, B., \& Matsumoto, S. (2003). Psychological factor affecting travel mode choice (case: bus-lane plan for Yogyakarta, Indonesia). Journal of the Eastern Asia Society for Transportation Studies, Vol.5, 426-436.

19. Gebeyehu, M., \& Takano, Shin-ei. (2008). Modeling the relationship between travelers' level of satisfaction and their mode choice behavior using ordinal models. Journal of the Transportation Research Forum, Vol. 47, No. 2, 103-118.

20. Burgmanis, G. (2012). Children's everyday school travel and mode choice in a post-socialist city: the case of Riga, Latvia. 2nd International Conference on Social Science and Humanity, IPEDR Vol. 31, IACSIT Press, Singapore.

21. Maulana, R., \& Yudhistira, M. H. (2020). Socio-economic factors affecting the choice of transportation mode in jakarta metropolitan area. Jurnal Pembangunan Wilayah dan Kota, Vol. 16, No. 4, 245-252.

22. BPS-Statistics of Sulawesi Utara Province. (2020). Sulawesi utara province in figures 2020.

23. Bollen, K. A. (1989). Structural equations with latent variables. Department of Sociology, John Wiley \& Sons, New York. 